\title{
The Attainment of Privatisation Objectives in Two Bulgarian Industries*
}

\author{
Tony Cox / Graham Hooley / Marin Marinov / Svetla Marinova**
}

Privatisation forms an essential part of the progress of Bulgaria towards a free economy. This paper reviews the objectives of privatisation, as exemplified by the UK model, and the conditions necessary for their achievement. It considers the privatisation processes in Bulgaria and their operation in reality in the construction and the beer industries.

Die Privatisierung bildet einen wesentlichen Teil des Fortschritts Bulgariens auf dem Weg zu einer freien Wirtschaft. Der vorliegende Artikel betrachtet die Ziele der Privatisierung, wie sie durch das "britische Modell" veranschaulicht werden, und die Bedingungen, die zu ihrer Erreichung notwendig sind. Es wird der Privatisierungsprozeß in Bulgarien und seine Auswirkungen in den Bereichen Bau und Brauereiwesen untersucht.

Manuscript received: 24.9.96, revised: 6.1.97, accepted: 24.1.97

** Tony Cox, born 1938, B.Sc., Ph. D., MBA, Senior Lecturer in Marketing, Aston Business School, Birmingham, UK. Main research interests include International Strategic Management and Marketing Strategy in both large companies and SMEs. Privatisation and FDI in developing economies.

Address: Aston Business School, Aston University, Birmingham, B4 7ET, England Email: a.j.cox@aston.ac.uk

Graham Hooley, born 1951, B. Sc., Ph. D., Professor of Marketing, Aston Business School, Birmingham, UK. Main research interests include Comparative International Marketing Strategy, Service Quality. Privatisation and FDI in developing economies.

Marin Marinov, born 1948, Ph. D., Senior Assistant Professor, Technological University, Sofia, Bulgaria. Main research interests include Comparative International Marketing Strategy. Privatisation and FDI in developing economies.

Svetla Marinova, born 1962, B. Sc., Research Student in Marketing, Aston Business School, Birmingham, UK. Main research interests include Comparative International Marketing Strategy. Privatisation and FDI in developing economies. 


\section{Introduction}

State-ownership of companies has been dominant in Central European countries, which are now in the process of reforming into free market economies. In the opinion of most Western analysts, privatisation is an essential part of this transitional process (Estrin 1994). A strict definition of privatisation merely involves the partial or total transfer of an enterprise to private ownership and control (Bös 1991), however, a number of writers argue that transfer of ownership is not sufficient to accomplish all the potential benefits of privatisation and that competition, liberalisation and deregulation are vital for private enterprise to flourish. In Central Europe, particularly important aspects of liberalisation include the exposure of the economy to foreign competition, and reform of the banking and legal systems (Lipton/ Sachs 1990; Fischer/ Gelb 1991; Portes 1993; Cook/ Kirkpatrick 1988). A particularly sensitive issue in the case of the emerging free market economies of Central Europe, is that privatisation is seen to operate to the national benefit. Large scale privatisation clearly changes the distribution of power in a society with decisions on prices, investment, and technology being taken out of the hands of public policy makers and placed in the hands of managers who are responsible to private shareholders. If too many of the shares are bought by overseas investors, the country's economic control can be perceived as moving into foreign hands (Graham/ Prosser 1987).

In what follows, these issues are explored in the context of the Bulgarian privatisation programme. The Western view of the benefits of privatisation and the conditions required for their achievement are reviewed. The Bulgarian privatisation process is then presented and propositions drawn concerning the potential achievement of the benefits of privatisation in Bulgaria contingent on the differences between the UK privatisation model and the Bulgarian reality. These propositions are then tested in the Bulgarian construction and brewing industries. The paper presents empirical results and discusses these in the context of the UK model of privatisation. Amendments to this model for the Bulgarian case are presented in the light of the empirical results.

\section{The UK Model of Privatisation}

Vickers and Yarrow (1988) present a model where they envisage that in any company, state-owned or private, there are principals (the owners) and agents (the managers). The principal seeks to establish incentives for the agents who take decisions that affect the principal and contribute maximally to the principal's objectives. In state-ownership the agents act for the government departments who in turn act for the government. In private ownership the agents act on behalf of the shareholders. On this model, privatisation involves a shift in the objectives of the principal from public benefit to shareholder profit. This 
shift causes problems for all governments privatising state-owned companies in that they seek increased efficiency in the commercial operation of the economy but its pursuit often involves potentially unpalatable social and political consequences like redundancies and increased consumer prices. The dilemma is that governments often wish the privatisation programmes to fulfil, at the same time, both their own and shareholders' economic objectives and their additional social and political objectives. In the UK model, the dilemma is addressed through taxation policies, subsidies, and regulation (Times 8th March 1995).

In a study of the objectives of the UK privatisation process, Vickers and Yarrow (1988) identify the main objectives of the privatisation programme as including; reducing the public sector borrowing requirement, reducing government involvement in enterprise decision making, easing problems of public sector pay determination, gaining political advantage, widening share ownership, encouraging employee share ownership, and improving efficiency. Here, efficiency includes both the improvement of the companies' internal efficiency and the improvement of allocative efficiency whereby a wider variety of goods are available to the consumer with better quality and at reduced prices. The national economy is expected to improve with the achievement of these objectives due to an increase in international competitiveness.

\subsection{Objectives of Privatisation}

The general economic arguments are fairly well rehearsed by many writers (Bishop/ Kay 1988; Kay/ Mayer 1986; Bös 1991; Vickers/ Yarrow 1988; Beesely 1981; Hayek 1945; Kay/ Mayer/ Thompson 1986). These are discussed below.

\subsubsection{Relief of Government Budget Stress}

Here budget stress is alleviated by the obvious increase in government capital by the sale of assets, albeit at prices below the market value as an incentive to buyers, and by a removal of claims in the form of subsidies and subventions.

\subsubsection{Efficiency Benefits}

It is first necessary to distinguish between internal (also called technical or productive) efficiency and allocative efficiency. The former involves the reduction of production costs and greater internal company efficiency while the former refers to the reduction of prices and increased availability to the consumer because of greater market efficiencies.

Internal Efficiency

Internal efficiency is expected to increase on privatisation because of changes in management behaviour as managers should be less influenced by bureaucratic 
constraints and social responsibilities (Alchian/ Demsetz 1972) and are exposed to monitoring by shareholders, creditors, and the market.

\section{Allocative Efficiency}

Allocative efficiency is expected to improve not only because of better internal efficiency but also because of competitor comparison (Beesley/ Littlechild 1983). A problem arises when the service is attached to a social obligation which may erode profitability constraining private managers' pursuit of profitability. This is extremely important in the case of Bulgaria.

\subsection{The Need for Competition}

Research in both the USA and UK have found some evidence that privatisation produces greater internal efficiency (Kitchen 1976) but poorer allocative efficiency (Millward 1982; Boardman/ Vining 1987). Conversely, Caves and Christensen (1980) found that both allocative and internal efficiencies improve because of market competition. Thus there is evidence that where competition exists both internal and allocative efficiencies can improve.

\subsubsection{The Effect of Competitive Forces}

For competition to operate effectively there is a need not only for privatisation in the strict sense (transfer of ownership) but also liberalisation (opening up competitive forces). The consensus of opinion is that it is better to liberalise the entry conditions and let competition find its own natural level. In this situation privatisation in competitive markets causescompetition which regulates company behaviour and provides the incentives that balance internal and allocative efficiency (Baumol 1982). Thus an effective competitive process provides an incentives system that impels companies to behave so that efficient resource allocation is achieved but where the original public enterprise had a natural monopoly with extensive market power, and is not broken up prior to privatisation, deregulation is unlikely to produce the required increase in competition with the company merely erecting its own entry barriers possible because of its monopoly status. In the extreme situation market concentration may actually increase if predatory activities result in the demise of existing inefficient competitors (Schwartz/ Reynolds 1983). When competition is nonexistent or ineffective as in the case of large privatised companies, there is a need for a regulatory policy to impose allocative and internal efficiencies and to achieve the benefits of privatisation. This may also be required for governments to achieve their own political objectives. One of the most commonly used regulatory mechanisms is the introduction of a restrictive pricing policy with the clear objective of maintaining allocative efficiency (Kahn 1970; Fromm 1981; Crew/ Kleindorfer 1986). This pricing policy has fundamental implications for investment in the industry in that it restricts the return on investment for the companies. In consequence there is a reluctance for companies to invest in 
production efficiency which would reduce the costs of production (Averch/ Johnson 1962). As will be seen later, this government control is maintained in Bulgaria by the mechanism of manipulating the industry structure.

\subsection{Summary}

The benefits of privatisation can be divided into governmental benefits, national economic benefits, improved allocative efficiency benefits, and improved company efficiency benefits. These are not independent and the achievement of one set of benefits can constrain the achievement of others unless a careful balance of liberalisation and control is established. Transfer of ownership is not sufficient to accomplish the benefits seen for privatisation. Liberalisation and deregulation are vital for true private enterprise to flourish. From a theoretical point of view, to achieve all the benefits of privatisation there must not only be the sale of assets and the potential for re-investment and profits accruing to shareholders, but effective legislation must exist to allow reasonable entry of competition to all parts of the industry, including its task environment. On the other hand protective regulation must exist to ensure allocative efficiency. This is particularly important in the case of Central and Eastern Europe as the freeing of the market must be seen to not only improve government and company returns, but also this must demonstrably not be at the expense of the consumer. The present research provides an empirical investigation into the privatisation process in Bulgaria where it will be seen that all the theoretically required components of the privatisation process are not in place. The effects of this are studied in the brewing and the construction industries.

\section{The Official Privatisation Process in Bulgaria}

The reform process started in 1991 (Jones/ Rock 1994) when, for the first time, a non-socialist party (UDF) formed a government and introduced the Transformation and Privatisation Law. The balance of power, however, was held by the ethnic Turkish party (MRF) which caused difficulties in introducing further reform legislation and enacting existing legislation. As a result several enabling resolutions didn't come into being until late in 1992. In 1993 a coalition government was elected under the leadership of Lyuben Berov, a representative of the MRF, and the political process of creating privatisation law has further slowed due to the necessity of finding compromise solutions amongst the several factions involved. Although the process is monitored by a single State Privatisation Agency, there is no single focus for the process. The collapse of the UDF government has effectively caused the intended fast free market reform to be reduced almost to a halt (Celarier 1992a). A further impediment to the progress of effective privatisation progress is the dominance of powerful interest groups which are closely linked to the old system and to the old security apparatus with vested interests in maintaining the old power 
structure (Borger 1994). Consequently, macro-economic stabilisation is proving difficult with the prerequisites for an effective policy not yet in place causing continuing decline in output and rampant inflation (OECD 1992). It is recognised that a number of changes are required to stimulate the privatisation process and attract more foreign investment. These include effective changes to laws on the restitution of private property (Ryan 1992; Clague/ Rausser 1992) and reform of the banking system which is not well structured or controlled (Parker 1993). A more liberal foreign investment law is also needed (Celarier 1992b) as there are a number of restrictions to foreign participation in Bulgaria. There is no right of foreigners to hold land (Jones/ Rock 1994) and government approval is needed to set up JVs with more than $45 \%$ of foreign participation (Jermakowicz/ Drazek 1993). A further severe constraint on the amount of revenue that can be reinvested in the Bulgarian economy is the \$12bn overseas debt (Parker 1993; Frydman 1993; Celarier 1992). This not only restricts the amount of external investment in Bulgaria, but, potentially, repayments mean that earnings are not re-invested in the Bulgarian economy as they are being used to pay off the government debt. These problems mean that the Bulgarian economy is under severe pressure which in turn is affecting, both home demand for goods, and company output. Industrial output in 1991 showed an annual decrease of $12 \%$, with an associated annual reduction in the GDP of $20 \%$. In the same period, unemployment increased by 3\% (Buckley/ Ghauri 1994; Tietz 1994; Frydman 1993). Low efficiency is a characteristic of the national production (Manov 1991). Materials costs, capital costs, and import costs of Bulgarian goods are several times higher than the levels achieved in the highly developed countries.

These publicly known issues cast considerable doubt on the continuing progress of the reform processes and effectively discourage Western investment in Bulgaria with the consequent effect on economic progress and the introduction of competitive forces. In turn this casts doubt on the potential for achieving improvement in both internal and allocative efficiencies. In interviews with the ministries responsible for the privatisation process several other problems in the implementation of the privatisation process are identified.

\section{The Ministries' View of Bulgarian Privatisation in Practice}

Based on in-depth interviews with representatives of the ministries responsible for privatisation at both national and regional levels further problems are uncovered. Although there is an official government privatisation policy and laws have been passed that purport to stimulate economic activities and offer both incentives and protection to potential overseas buyers in the form of preferential tax incentives and legally defined minimum information on company and market performance. Although the legislation exists, it is acknowledged that there are many obstacles and hidden agendas in operation. 
The privatisation process is in the hands of the Director of the Privatisation Agency who has the sole decision making power. It is felt that he is influenced by the interests of the ruling political parties who are not wholly committed to the successful operation of the privatisation process. Furthermore the process is confused by the legally required intervention of several groups who introduce conflicting criteria for the successful completion of privatisation thus there is no national implementation of the privatisation policy. All privatisations are individually negotiated. In practice they go to the company offering the most money to the government. Surprisingly there is no proactive policy. The investors have to make the first move and persuade the Bulgarian government that they can offer enough.

\section{The Research Propositions}

Although privatisation and liberalisation legislation exists, it is not implemented in an effective way. One consequence of this is that little progress has been made in process of privatisation. As a result there is little competition in Bulgarian industry and even where an industry has been privatised, much of the task environment of that industry in the form of suppliers and customers, remains in the hands of the state. This leaves little flexibility in the hands of the industry to improve efficiency by optimising its raw material cost and pricing policies. The lack of competition also means that there is no incentive for companies to improve the allocative efficiency. Improvement of internal efficiency, in theory, should also result from the re-investment of profits into the company to modernise machinery and processes, but because of the poor economic state of the country and its large outstanding debts, the government takes much of this profit via taxation to ease these government problems so that little re-investment in the privatised company is possible. This leads to the three research propositions:

1. Privatisation in Bulgaria is focused on the relief of Government stress

2. There is no improvement in internal efficiency

3. There is no improvement in allocative efficiency

\section{Methodology}

A case study methodology was adopted and used semi-structured interviews with key personnel in 7 companies, four in the construction industry and 3 in the brewing industry. this approach was adopted in order to gain in depth insight into the operation of the privatisation process at industry and company levels. The results are therefore not nationally generalisable but are representative of the respective industries studied. This is especially true of the brewing industry with its oligopolistic nature. The industries were chosen as they have very 
different industry structures and allow the effects of industry infrastructure on the efficacy of the privatisation process to be studied. In addition it is also important to note that these two industries have attracted most foreign investment in Bulgaria and are, therefore, of national strategic importance. Interviews were also carried out with the government agents responsible for the implementation of the privatisation process at national and local levels. The interviews in the companies were conducted with the people fulfilling the functions of chief executive and other functional managers. In this way it was possible to investigate not only the process of privatisation but also the implications of the process in relation to the company and industry structures.

\section{Results}

\subsection{The Construction Industry}

In depth interviews were carried out with four companies in this industry. Although all were in the construction industry they represented various sizes of company, various ownership structures, and different market stances. In this way it was possible to study the issues identified above over a reasonably wide base in the industry. Each case is discussed separately below and then some more general conclusions are drawn concerning the Bulgarian construction industry.

\section{Company 1}

The company operates on a regional basis only where it has a virtual operational monopoly. Thus there is no competition for the processes it carries out. However, both the suppliers of its raw materials and the clients for its products/services are state-owned. Consequently, although the company is privatised, its business is still under the control of the state via these suppliers and clients. The company is owed considerable amounts of money for services rendered with little prospect of their immediate repayment. It is thus subsidising state-owned enterprise. The high rates of inflation compound the consequences of delayed payments whereby clients obtain the products/services at reduced prices. The state of the technological development of its plant and machinery is rated as poor compared with international standards with little opportunity for re-investment.

\section{Company 2}

This company operates on both a national and regional level and is in the position of having to tender for business. In its regional business it has only one competitor but in the national arena competition is severe with many competitors. The Government controls the prices paid for its products via auctions (tenders) organised by the Chamber of Construction. Thus as in the 
previous case, state controlled industry and the Government are actually the customers with little privatisation in the forward direction. The Government makes sure that it also benefits from this situation by the financial terms of the contracts. Again these state-owned customers are allowed to defer payment for several years by decree and hence benefit from inflation decreasing the real cost of goods/services that are purchased. In the backwards direction the situation is more competitive because the company imports components and raw materials from the Western world. Thus competitive forces control the price and quality of supplies. However, because of the strict price controls in place in the forwards direction the company has strict price limits on the supplies it can afford and true competition is again limited.

\section{Company 3}

Unlike the previous two cases it is the world competitive stature of the purchasing company which was important. It is selling its products in the world market, under the parent company's name, where competition exists and where the Bulgarian Government has no control. In this situation the efficiency of the Bulgarian SBU has to increase, requiring the injection of financial resources into new plant and machinery in order to remain competitive in the world market.

\section{Company 4}

In this case the purchaser enjoys a world-wide reputation and competitive edge. The purchased company has a virtual monopoly (95\%) in the national Bulgarian market. As might be expected in these circumstances the manufacturer holds the balance of power over both suppliers and distribution. In the case of suppliers the company is backwards integrated and its distributors are awarded only a 1 to 2 year contract. Only 8\% of these distributors are state-owned. Thus the Government has benefited from the cash generated by the sale of the company and internal efficiency is improved by the modernisation of the technical plant, however, because of the monopoly situation, there is no guarantee of any improvement in allocative efficiency.

The evidence suggests that a distinction needs to be drawn between the companies that are privatised domestically through management buyouts and those privatised with FDI. In companies of the former type little or no help was given to the companies and the asset valuations were manipulated via the ZUNK to maximise Government returns from the process. There was also a heavy tax burden allowing little opportunity for reinvestment in the privatised company. There was no real privatisation of the wider industry with suppliers and customers either remaining in state ownership or being indirectly under state control. In the case of these companies, any profits were taken by the Government to ease its own financial situation and the wider industry structure 
and deferred payment decrees mean that these privatised companies are subsidising their state-owned suppliers and customers. Because of this, and the lack of competition, there is no opportunity for improvement in internal efficiency. Allocative efficiency is not improved because price reductions cannot be achieved by the privatised companies with their heavy tax burden and the need to generate revenues to survive. In both of these cases it would seem that the Government did not wish to encourage the process and simply took the opportunity to rid itself of liabilities and take as many revenues as possible with no thought to the long term development of the company.

The situation for companies privatised through FDI is very different. The Bulgarian companies concerned were large and had the potential for attracting high selling prices as well as for participation in international markets where hard currency would be earned for the Government. The purchasers were of high international standing bringing and an associated high bargaining power with the Bulgarian Government. The criteria for the choice of the purchaser by the Government was the price that was offered and the debt liability which would be taken off the Government's hands. In return for this considerable concessions on tax and retention of earnings were offered. Thus the Government was again maximising the achievement of its own objectives and it could be argued that an accidental consequence of this was the improvement of internal efficiency due to the incorporation of the Bulgarian companies into international companies and their participation into competitive world markets. Thus the effect of competition on improving internal efficiency is seen. The other aspect of improving allocative efficiency for the Bulgarian population is not achieved as the Bulgarian companies were used merely as manufacturing units for their large international purchasers.

The cases discussed above support the reservations expressed about the Bulgarian implementation of the privatisation process where it was argued that only the relief of government stress would be achieved in the case of the entirely domestic privatisations. The conclusions, however, need to be modified in the cases of FDI where the main objective was still the relief of government stress but because of the high bargaining power of the purchasing companies concerned they were able to negotiate concessions which enabled the improvement of internal efficiency and modernisation to be achieved. In no case was there any evidence of improvement in allocative efficiency in the Bulgarian economy. It is interesting to note the differences in the Government stance in the cases of FDI in relation to the timing of the privatisation. In the earlier privatisation the Government retained an interest in the form of shares which could be interpreted as them retaining some degree of control, although this appears not to have been exercised. 


\subsection{The Beer Industry}

\subsubsection{Industry Background}

The industry was established in the 1880s with the creation of breweries in Shoumen, Plovdiv, and Sofia. The present day industry is well developed with thirteen brewing companies spread all over the country having a total annual capacity of about $55,000,000$ hectolitres. There is a certain amount of concentration in some of the industry's processes with two enterprises, one in Elin Pelin, and a new large in Yambol, responsible for the majority of malt production. A further five enterprises undertake most of the bottling. The industry as a whole also has a research institute for beer and hop production development and a large plant for the production of spare parts and nonstandard equipment. The majority of raw materials are produced in Bulgaria. Ninety to ninety five per cent of the brewing barley is raised in Bulgaria and the rest is imported. Bulgaria produces some $50 \%$ of the required hops and hop products with a further $50 \%$ being import from China, South Korea, the Czech Republic. Many non raw material such as filtration materials, stabilisers and enzymes are imported. Because of the lack of investment in the brewing industry the state of technological development is far below the world average standard. Existing equipment is highly non standard and mostly imported from Germany, Belgium, France, Denmark and Italy. There is some local production of low technology equipment like bottling lines, air compressors, and refrigerator and steam installations. The main products are cask, bottled and canned lagers ranging from ordinary quality fairly weak beer to high quality stronger specialist beers. The former is mainly sold on the domestic market while the latter is exported. The export market accounts for only a small percentage of production with cash sales in the USA, the UK, Austria, Afghanistan, Lebanon, Italy and Greece. It is also exported via barter and countertrade with CIS countries, Romania and Poland. Only three Bulgarian breweries participate in the high quality Western markets, earning some 2 million US dollars annually. The industry hopes to increase these beer sales abroad and to start exporting malt. The domestic market has suffered badly from Bulgarian inflation, with the purchasing power of the average Bulgarian decreasing with the consequent fall in home demand, from increased taxation. Both of these mean that re-investment in the industry is difficult. Thus the Bulgarian beer industry is essentially polarised with the big three brewers dominating the export markets and the smaller ones having to compete in the declining domestic market. Increasing inflation and tax burden is causing difficulty in re-investing into the industry. In contrast with the construction industry there is real competition but the effect of this is that the number of small brewers is likely to decrease as they become unable to compete with the big brewers. It would seem, therefore, that competition is unlikely to increase allocative efficiency with a decrease in the number of brewers and that internal 
efficiency will increase only in the three big companies as a result of competition between them but as a result oligopolistic conditions will arise as the smaller brewers are forced to cease trading.

\subsubsection{Interview Results}

\section{Company 5}

The company is, to a large extent, vertically integrated around the products and equipment associated with its core business of brewing beer. It produces malt and has its own bottling plant and distribution network. Parts of this chain are now inadequate for its needs, especially the bottling plant whose deficiencies give the company's competitors a competitive edge in this area. Its main market is the Bulgarian domestic market, but it does sell a number of premium beers to the Western market. The strategy of the parent company is to pursue market share in both the domestic and overseas markets. It depends on the state-owned malt producers for its supply of raw materials which allows some form of Government control but because of its large size and market share the company has considerable negotiating power. Not withstanding this, the Government is able to extract revenues from the privatised company through the prices the state-owned malt producers charge for their products.

\section{Company 6}

The brewery was privatised through Bulgarian investment capital although there is a management agreement with an overseas international standard brewing company. It operates in the same markets with the same product range as company 5. It owns its own distribution network and in addition distributes its products through a further 20 private wholesalers who hold one year contracts which the brewery operates as a performance control mechanism. Because of the lack of overseas investment the brewing equipment is more obsolete than that of others in the market. Again the company's main market is the Bulgarian domestic market and it also operates in the UK market where $10 \%$ of its products are sold. It depends on the state-owned malt producers for its supply of raw materials allowing further Government control and potential for extracting revenues.

\section{Company 7}

The overseas investor is a large international company. Again, because of the lack of investment the brewing equipment is of a low technological level compared with that found in the West. The company's strategy is to gain market share in the Bulgarian national and regional markets and competes with the previous two companies in these markets. Its supply and distribution chains are similar to the previous two breweries with the distinction that it contracts out 
some of its distribution to third parties who are contracted on an annual basis. It also has one year contracts with the suppliers of barley and malt. Again the state-ownership of the malt producers allow Government price control.

The main characteristic of the brewing industry is its Government engineered mixed structure. The main competitors are a mixture of FDI ownership and Government controlled domestic ownership. The industry structure also exhibits a mixture of private and state-owned components. The suppliers of raw materials are largely state-owned while the majority of end users are private individuals supplied by a largely private and fragmented distribution network. The industry is also focused mainly on the Bulgarian domestic market. This mixed nature allows the Government of exert a large degree of control over the industry in order to achieve its financial objective of increasing its revenues and at the same time guarantees modernisation of the industry from foreign investment. This is achieved by preferential treatment of the Government influenced competitors affecting an effective subsidy to enable them to sell their products at low prices. In turn this forces the foreign owned competitors to match these prices in order to be competitive in the domestic market thereby ensuring investment in modern technology and production processes. Revenues to the Government are also guaranteed by the state control of the raw materials supply. The result of this situation is that the Government channels the foreign investment funds into its own revenue account. By means of the mixed ownership of the main competitors The mixed structure of the industry allows the Government to achieve all the classical objectives of privatisation while still maintaining considerable control over its revenue collection not by the introduction of true competition but by engineering the industry structure in its favour. This industry structure cannot be said to involve competition in the conventional sense of free competition but, a Government inspired artificial competition exists for the FDI companies which ensures that both internal and allocative efficiencies exist. While beneficial to the consumers in the market and to the modernisation of the industry, there is a feeling that the achievement of the improvement in these efficiencies is a secondary consequence of the Government actions. In terms of the research propositions, the evidence from the brewing industry indicates that the main aim of the Government in Bulgaria is, as suggested, to relieve its financial stress. In addition, by the way that it has manipulated the industry structure, it has also achieved the other objectives of privatisation of improving the internal and allocative efficiencies by the introduction of a state controlled competitive element. This, however, was done primarily in order to channel foreign investment into state revenue accounts.

\section{Final Discussion and Conclusions}

The initial research proposition, following from the literature review and the description of the privatisation process in Bulgaria, was that the main emphasis 
of the process was on the relief of Government financial stress and that neither internal nor allocative efficiencies were likely to be achieved. This has proved to be so in only in the case of companies in the construction industry which were not privatised by FDI. In all other cases there was some degree of improvement in internal and allocative efficiencies. These were not achieved, however, by the mechanisms advocated in the UK model of privatisation. The mechanisms involved were specific to the companies and the industries concerned. These are discussed below where the two industries are considered and the differences between non-FDI and FDI privatisations are illustrated.

In the case of the construction industry, the non-FDI privatisations were implemented by management buy out and involved the managers raising capital from largely state sources. The repayment of interest on the loans and tax levies were paid from the operating revenues. In the cases considered, this left the company in debt with the consequence that no re-investment was possible with no improvement in the internal efficiency of the companies. The industry structure was largely state controlled with both suppliers and customers still being in state ownership. This provided the government with control over cost of materials and product prices. The conditions of this control was such that the privatised companies were subsidising the rest of the largely state-owned industry. As the distribution system was unaltered, there was no improvement in allocative efficiency. Thus in this situation, the research proposition was found to be supported. The construction industry privatisations carried out via FDI present a different picture. In both the cases studied, the purchasing companies were large and involved in international trade. In markets outside Bulgaria, the Bulgarian products were rebadged and sold under the purchasing companies' brand name. Thus the objective of relieving government financial stress was attained in an important way. Not only did it receive the proceeds of the sale but also received payment for the companies' products in hard currency via the taxation on the companies. Internal efficiency was also improved as the investing company was forced to invest in improving the plant and processes of the company in order to bring the products up to internationally acceptable standards. Very little was achieved in the improvement of allocative efficiency in the Bulgarian market place. Clearly when the company was involved in overseas markets only, there was no effect on the distribution in the Bulgarian market place. When the company also traded in the Bulgarian market, it might be expected that products would be more widely available, however, the prices of the products were set at world levels which few Bulgarians could afford. Thus in the case of FDI privatisation in the construction industry two of the privatisation objectives were achieved, namely the improvement in the governments hard currency finances and in the internal efficiency of the production processes. 
In the case of the brewing industry the government has engineered a mixed industry structure with both private and subsidised state-owned companies being involved. This ensures competition but this in a different way to the conventional Western system. In Bulgaria the existence of government subsidised cheap products forces the privatised companies to sell their products at low prices in order to compete in the domestic market which is the main market for the industry. The market is dominated by the three large companies considered in this study and their relationship is discussed below. The non-FDI privatisation was accomplished through a Bulgarian investment agency thus was essentially government funded. It seems to have been set up to provide subsidised competition for the foreign owned brewing companies and prevent an overseas monopoly of the industry allowing the government to keep at least indirect control. In order for it to be competitive with the foreign owned companies the government encourages re-investment and forces it to sell its product at reduced prices. As such internal efficiency was improved by the modernisation of its processes and allocative efficiency is improved because of the subsidised low prices. These improvements, however, appear not to be the main motivation of the government which was to institute artificial competition for the foreign owned companies in order to achieve maximum benefit from the FDI privatisations. In the case of the FDI privatisations, certainly government funds were improved by the sale of assets and from the tax returns. The fact that the foreign companies also have to compete with the government subsidised brewery and have a larger market share means that they are indirectly subsidising the state-owned brewery. The necessary modernisation of processes and improved management expertise means that the internal efficiency of the companies are improved as is allocative efficiency because of the artificially low prices charged in the market place. Hence the conventional objectives of privatisation are met in the brewing industry but this is made possible, not by the introduction of true competition, but by a government manipulated mixed industry structure.

\section{References}

Alchian, A./ Demstz, H. (1972): Production. Information Costs and Economic Organisation, in: American Economic Review, Vol. 62, pp 777-795.

Averch, H./ Johnson, L. (1962): Behaviour of the Firm Under Regulatory Constraint, in: American Economic Review, Vol. 52, pp 1052-1069.

Baumol, W.J. (1982): Contestable Markets, in: Amercian Economic Review, Vol. 72, pp 115.

Beesley, M. (1981): Liberalisation of the use of British Telecommunications Network, London, Department of Trade and Industry.

Beesley, M./ Littlechild, S. (1983): Privatisation: Principles. Problems and Priorities, in: Lloyds Bank Review. Vol. 149, pp 1-20. 
Bishop, M./ Kay, J.A. (1988): Does Privatisation Work?, in: Centre for Business Strategy, London Business School.

Boardman, A.E./ Vining, A.S. (1987): A Comparison of the Performance of Private. Mixed and State-owned Enterprises in Competitive Environments, in: Working Paper 1206. Faculty of Commerce, Columbia University. New York.

Borger, J. (1994): Left Steers Sofia Away From the West, in: The Guardian, 8th. March, pp 13.

Bös, D. (1991): Privatisation: A Theoretical Treatment, Clarendon Press, Oxford.

Buckley, P.J. and Ghauri, P.N. (eds.) (1994): The Economics of Change in East and Central Europe, Academic Press.

Caves, D.W./ Christensen, L.R. (1980): The Relative Efficiency of Public and Private Firms in a Competitive Environment, in: Journal of Political Economy, Vol. 88, pp 958-976.

Celarier, M. (1992): Bulgaria's Slow Trek to the Market, in: Global Finance, Vol. 6, pp 6974.

Celarier, M. (1992): A Political Hiatus Puts Bulgarian Reform on Hold, in: Global Finance, Vol. 6, pp 42-43.

Claque, C./ Rausser, G.C. (eds.) (1992): The Emergence of Market Economics in Eastern Europe, Blackwell. Oxford.

Cook, P./ Kirkpatrick, C. (1988): Privatisation in Less Developed Countries, Harvester Wheatsheaf, New York/ London/ Toronto/ Sydney/ Tokyo.

Crew, M.A./ Kleindorfer, PR. (1986): The Economics of Public Utility Regulation, Macmillan, London.

Estrin, S. (ed.) (1994): Privatisation in Central and Eastern Europe, Longman, London.

Fischer, S./ Gelb, A. (1991): Issues in Socialist Economy Reform, in: WPS 565, World Bank, Washington DC.

Fromm, G. (ed.) (1981): Studies in Public Regulation, Cambridge MA, MIT Press.

Frydman, R./ Rapaczynski, A./ Earle, J.S. (1993): The Privatisation Process in Central Europe, Central European University Press.

Graham, C./ Prosser ,T. (1987): Privatising Nationalised Industries: Constitutional Issues and New Legal Techniques, in: Modern Law Review, Vol. 50, pp 16-51.

Hayek, F.A. (1945): The Use of Knowledge in Society, in: American Economic Review, Vol. 35, pp 519-530.

Jermakowicz, W./ Drazek, C. (1993): in: Artisien, P./ Rojec, M./ Svetlicic M. (eds.): Foreign Investment in Central and Eastern Europe, St. Martin's Press.

Jones, D./ Rock, C. (1994): Privatisation in Bulgaria, in:, Longman, S. (ed.):Privatisation in Central and Eastern Europe, Estrin.

Kahn, A.E. (1970): The Economics of Regulation, Vol.s 1 / 2, Wiley, New York.

Kay, J.A./ Mayer, C.P./ Thompson, D.J. (1986): Privatisation and Regulation, Clarendon Press, Oxford. 
Kitchen, H.M. (1976): A Statistical Estimation of an Operating Cost Function for Municipal Refuse Collection, in: Public Finance Quarterly, Vol. 4, pp 56-76.

Lipton, D./ Sachs, J. (1990): Privatisation in Eastern Europe: The Case of Poland, Brookings, in: Papers on Economic Activity, Vol. 2, pp 293-341.

Manov, V. and Stoyanov, D. (1991): Macro-economic Assessment of the Changes in the Foreign Economic Links of Bulgaria, in: Soviet and Eastern European Foreign Trade, Vol. 27, pp 3-35.

Millward, R. (1982): The Comparative Performance of Public and Private Ownership, in: Roll. E (ed.): The Mixed Economy. Macmillan, London.

Parker, J. (1993): Eastern Europe - Step B: Banking and Budgets, in: Economist, Vol. 326, pp 15-17.

Portes, R. (ed.) (1993). Economic Transition in Central Europe, CEPR. London.

Ryan, J. (1992): Bulgaria: The Politics Are Right, in: Euromoney, p 77.

Schwartz, M./ Reynolds, R.J. (1983): Contestable Markets: An Uprising in the Theory of Indiustry Structure, in: American Economic Review, Vol. 73, pp 488-490.

Suzumura, K./ Kiyono, K. (1987): Entry Barriers and Economic Welfare, in: Review of Economic Studies, Vol. 54, pp 157-167.

Tietz, B. (1994): The Opening Up of Eastern Europe, in: Buckley, P.J./ Ghauri, P.N. (eds.): The Economics of Change in East and Central Europe, Academic Press.

Times Newspaper (1995), 8th March.

Vickers, J.S./ Yarrow, G. (1988): Privatisation: An Economic Analysis, MIT Press.

Weizsacker, C.C.v. (1980): A Welfare Analysis of Barriers to Entry, in: Bell Journal of Economics, Vol. 11, pp 399-420.

Williamson, O.E. (1975): Markets and Hierarchies: Analysis and Antitrust Implications, New York.

World Bank (1986): Annual Report 1986, Washington DC. 